\title{
AFRICAN ART: AN IMPETUS BUT IMPLICIT MAGNITUDE OF ARCHITECTURAL THOUGHT IN BAUHAUS SCHOOLING
}

SAYED AHMED AND FARID AHMED SUMAN

(Received 25 September 2014; Revision Accepted 15 October 2014)

\begin{abstract}
African art had a consequential inspiration for its aesthetic value over avant-garde mutiny, while the European artistic thought came to recognize the perpetual aspect of its composition and adapted these characteristics to evade naturalism which defined Western art, since the Renaissance. Architecture has opprobrium for its late response to any transformation of what other arts embrace certainly. But still, this 'frozen music' echoes the African 'muddy or woody' lyrics in its most constructive era of evolution; the zenith of Bauhaus. Why was this synthesis possible? To architecture, it is still regarded as a craft and the craftsmanship steered this communication to materialize both in elegiac comprehension and lucid scrutiny. The search for the sculptural need over architectural similes was probably to stimulate architecture in such way that is somewhat more humane. In fact, our retort to the nature is inevitable and such desire creates Metaphor and fabrics over symbolic representations which are experienced through climate, obtained by sensuous discernment of human being in what is referred to'primitive'. Supplementary curriculum from the early Bauhaus school demonstrates the emphasizing practice of its unique connotation. Likewise, Uses of indigenous constituents got a different dimension, which were distinct in Modernist practice of African architecture. This, along with the curse of 'unaesthetic', could be better explained by the modern theory of fractal art; which is something beyond our conformist splendor.
\end{abstract}

KEYWORDS: African art, African artifacts, Fractals, Cultural Exchange, Stylistic Influences, Bauhausand Modernism

\section{INTRODUCTION}

The idea of Bauhaus was the 'Einheitskunstwerk' (total work of art), translated into the collective needs of a modern society. But this idea of collectivity was easier stated than achieved. At the Bauhaus, "abstraction" took a different meaning as a search for fundamentalism. Abstraction did not stand in for "something else," rather it was the process of distilling art making down to the essentials. Having achieved that level of creative clarity, the artist could be redefined as "a builder of systems." The emphasis on experience over knowledge meant that communication between viewer and maker should be prelinguistic and immediate due to the eloquence of "fundamental forms"- a new philosophy comes out of Bauhaus. (Griffith, 2000) The fundamental approach of the Bauhaus was to see things with fresh eyes, to discard old notions. Paul Klee called this approach "visual thinking." This "reversal of values" moved the school away from the reform of arts and crafts to an engagement with the industrial world. Clearly, The famous art school; the Bauhaus had been profoundly fondled by the art and design.

Sayed Ahmed, Department of Architecture, Bangladesh University, 3/3 Asad Avenue, Dhaka-1207, Bangladesh.

Farid Ahmed Suman, Department of architecture, Bangladesh University, Bangladesh. 


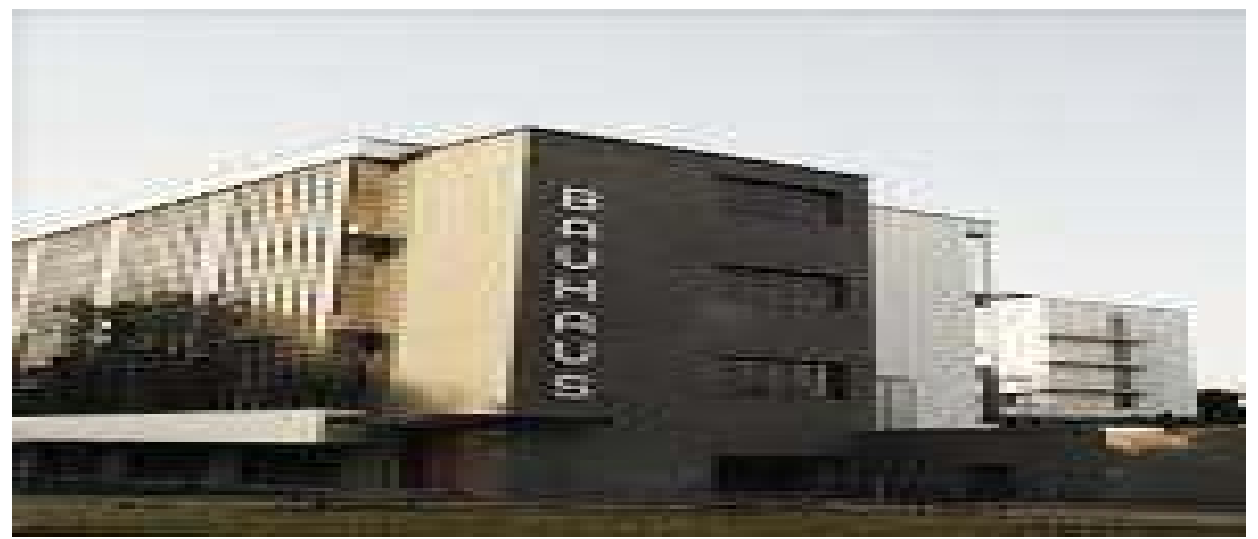

Figure 1: Bauhaus building, Dessau; 1925-1932

The Bauhaus, was not innovative in the fine arts but was very avant-garde in the world of design and architecture. Thus, the philosophy of the Bauhaus passed beyond the Werkbund spirit that the artist should be a craftsperson first and any aesthetic must be based upon sound dexterity. The whole notion of "craft" and making had to get beyond the medieval mystique and into mass manufacture. (Wilmette, 2011).

Exactly somewhat, Walter Gropius issued the Bauhaus (house of building) Manifesto in April 1919. In Germany, the subject matter of New Objectivity was highly active and provocative and confrontational but the styles employed by the artists were deliberately from old world, especially from Africa. The reason was, during the early 1900's; the avant-garde artists, their dealers, and leading critics of the era were among the first Europeans to collect African sculptures and masks for the aesthetic value on their way to Modernism.

Fiфure 2: Walter Gropius (1883-1969)

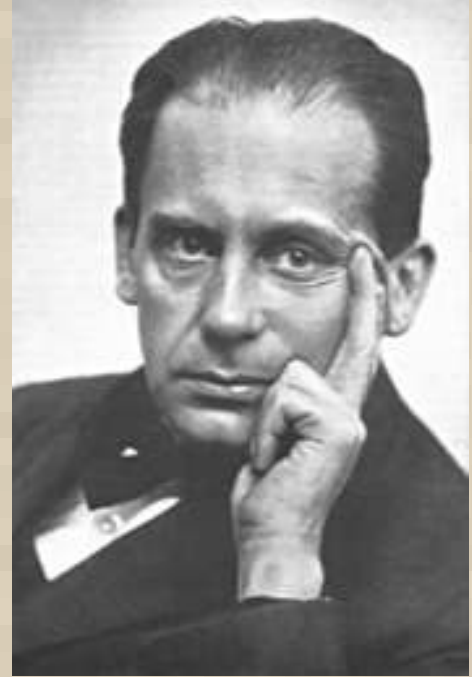

"Let us collectively desire, conceive and create the new building of the future, which will be everything in one structure: architecture and sculpture and painting, which, from the million hands of craftsmen, will one day rise towards heaven as the crystalline symbol of a new and coming faith. 


\section{Background}

\subsection{The Europe}

Starting in the 1870s, thousands of African sculptures arrived in Europe in the aftermath of colonial conquest and exploratory expeditions. They were placed on view in museums such as the Muséed'Ethnographie du Trocadéro in Paris, and its counterparts in cities including Berlin, Munich, and London. At the time, these objects were treated as artifacts of colonized cultures rather than as artworks, and held so little economic value that they were displayed in pawnshop windows and flea markets. While artworks from Oceania and the Americas also drew attention, especially during the 1930's Surrealist Movement; the interest in
non-Western art by many of the most influential early modernists and their followers centered on the sculpture of sub-Saharan Africa.

For much of the twentieth century, this interest was often described as Primitivism, a term denoting a perspective on nonWesterncultures that is now seen as problematic. (Davis, 2014)In France, Henri Matisse, Pablo Picasso, and their School of Paris friends blended the highly stylized treatment of the human figure in African sculptures and masks with painting styles derived from the postImpressionist works of Cézanne and Gauguin. The resulting pictorial flatness, vivid color palette, and fragmented Cubist shapes helped to define early modernism.

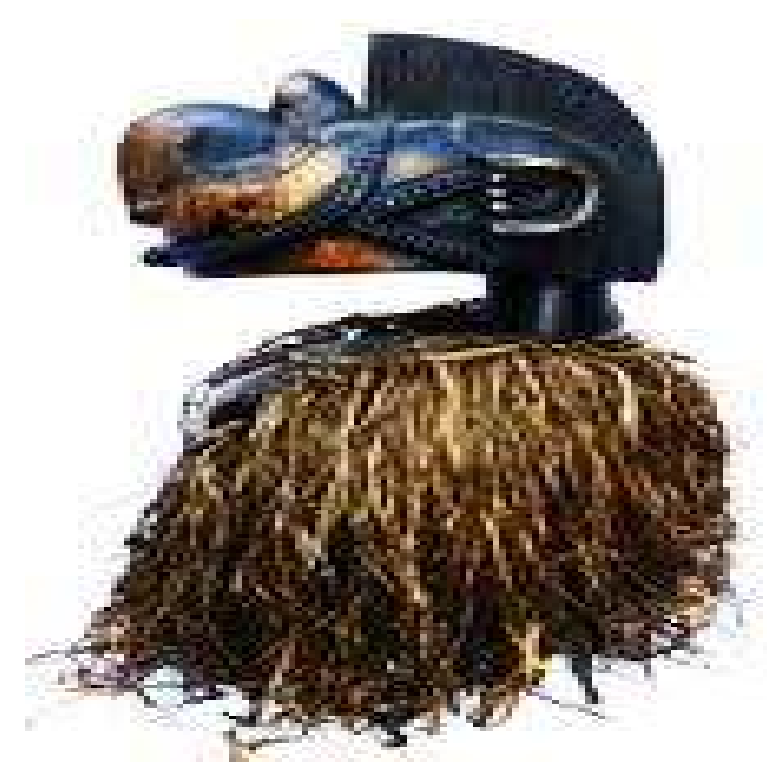

Figure 3: Nimba mask of Baga people, Guinea, West Africa

The Expressionists' interest in nonWestern art intensified after a Gauguin exhibition in Dresden in 1910, while modernist movements in Italy, England, and the United States initially engaged with African art through contacts with School of Paris artists.

The modernist concept of art wasdrawn to primitive art work such as Nimba ceremonial mask to redefine the nature of modern art. Its magical force and sense of irrationality overwhelmed the artistic mind of west which the avant-garde artist found very strong eventually. According to Picasso, Western art were too far from the magical root of image-making.(Faulkner, 1986)

\subsection{Deutschland}

According to art history, 'Die Brücke' (The Bridge) artists found instead inspiration in medieval 
German art and primitive African sculpture to connect with. In addition, Expressionists looked outside mainstream European society for inspiration, from far-flung tribal societies in Africa to the peasantry and folk art traditions closer to home. German Expressionist painters such as Ernst Ludwig Kirchner of Die Brücke (The Bridge) group, based in Dresden and Berlin, conflated African aesthetics with the emotional intensity of dissonant color tones and figural distortion, to depict the anxieties of modern life, while Paul Klee of the 'Blaue Reiter' (Blue Rider) in Munich developed transcendent symbolic imagery. For instance, The Scream of Edvard Munch in 1883 is regarded as an iconic propaganda of the existential anguish of the post-industrial modern age, an intensely psychological and emotional theme that was a major influence on the development of German Expressionism in the early 20th century. It may have been partly inspired by the raw quality of African tribal art. African art historian, Eckart von Sydow, defined the German emotional content as mystical; the German expressionists were not involved in penetrating the structure of these works from the dilemma point-Barbarous fetishes, grandeur, or both; while the Cubists were better able to extract the architectonic quality of the African sculpture. (Delange, 1967)

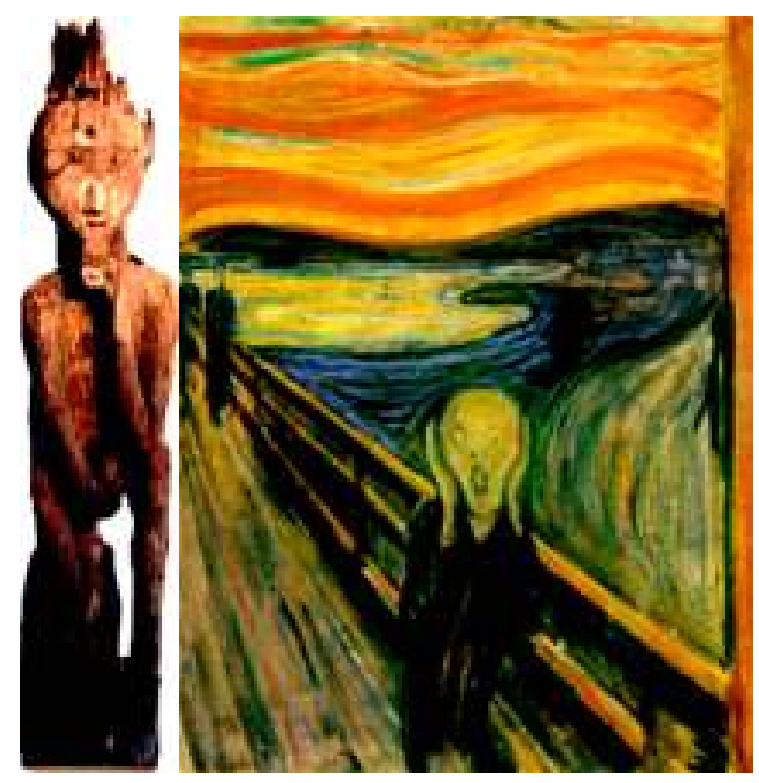

Figure 4: African art, inspiration of the painting 'Scream' German expressionism trend 1883

Again, from the political history of German empire, the colonial rule might have bifunctioned and eased the cultural exchange with Africa. The followings were German African protectorates and colonies in Africa, during 18841919:

1. German East Africa (Ostafrika): area comprise of Tanganyika (present-day Tanzania), Ruanda-Urundi (present-day Rwanda and
Burundi), Wituland (now in Kenya) and the Kionga Triangle in Portuguese Mozambique.

2. German South-West Africa (Südwestafrika): the region engulfs Namibia in present days and a part of Botswana.

3. German West Africa (Westafrika): Kamerun, after World War I, separated into a British partCameroons and a French Cameroun, later became present Cameroon. The British part was 
later split in half, with one part joined Nigeria and the other attached to Cameroon. Also, the empire includes Kongo, Gabon and Togoland. After
World War I it separated into two parts: a British part which joined Ghana and a French one, which remained as Togo.
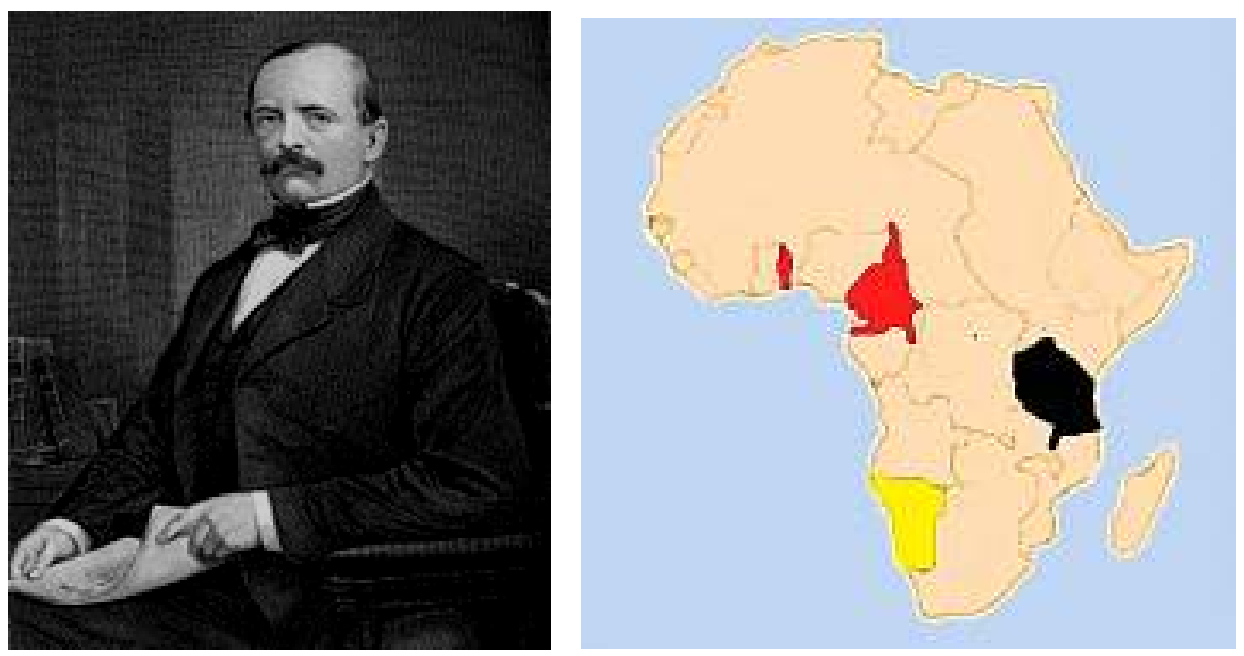

Figure 5\&6: German colonies in Africa(1884-1919)and the first Chancellor Otto von Bismarck (18151898)

The legislation broadly confined within the limits imposed by Portuguese Mozambique in south, the lake Nyssa and Tanganyika in east; the Guinea coast at west shores and Lake Victoria in north- a fairly compact empire of 38400 square miles was formed in 1885, the red letter year of German colonial history under the reign of Bismarck. (Dawson, 1919)

\section{Objective of the study:}

Based on the analysis of African sculpture and mask, with their aesthetical values; this study is an appraisal of Bauhaus school and its legislation for African art. The primary focus of the study is to delineate the exchange of ideas and their synthesis to form a revolutionary trend in architecture, implicitly. This study has three main objectives, as demonstrated underneath:

1. To ascertain the causes of adopting African art as an emancipation for the freedom of war-fatigued western mind.

2. To reconnoiter the possible opportunities to discover the African art with new dimension.

3. To recommend the insights which shaped traditional African architecture associated with African art that advanced the need for scholar promotion in modern architectural practice of Africa.

\section{Methodology of the study:}

This revision is emphasized on the synthesis of symbolisms, found through African essence at Bauhaus practice regardless of any timeline. Conjoint concerns of modernist practice in architecture, where African art was an inspirational cultural aspect to silhouette the triumph of Bauhaus tradition have been discussed in the study. Besides, how the trend influenced the practice of indigenous materials over building technology has been discussed with appropriate case studies. The enquiry is based on two comprehensive slants:

1. To establish a Theoretical framework for descriptive analysis (based on literature review)

2. Deriving annotations from Empirical basis (based on analysis of the study) 
The analysis of the specific objective entails of the following footsteps are delineated next:

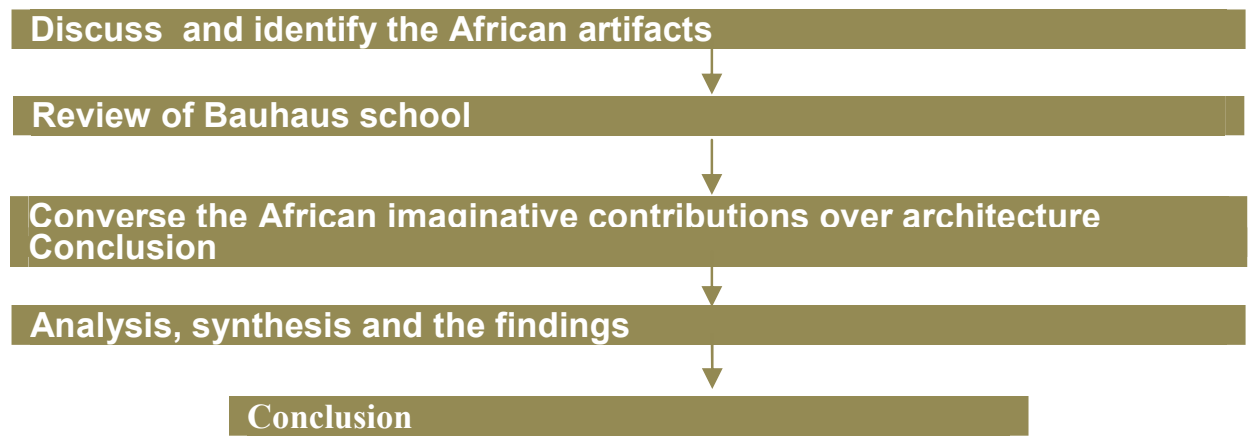

\section{What is African art?}

Ancestor worship, spirits, magic, and other rituals of the religion of African peoples have reflected in their art. African art is not anonymous. So artists were obliged to conform to the ancient artistic laws. This might be for the fair reason how peasant art and bushman art (started in Africa) both are always considered as 'applied'. It springs from a desire to impart color and gaiety to objects of daily use. It shows surprising tendency towards geometric abstraction. (Read, 1968)lf any innovation once proved to make these arts more effective, it became part of an ever-growing tradition. From the vast section of African art, this study is going to sublimate only three contextual sections for this paper.

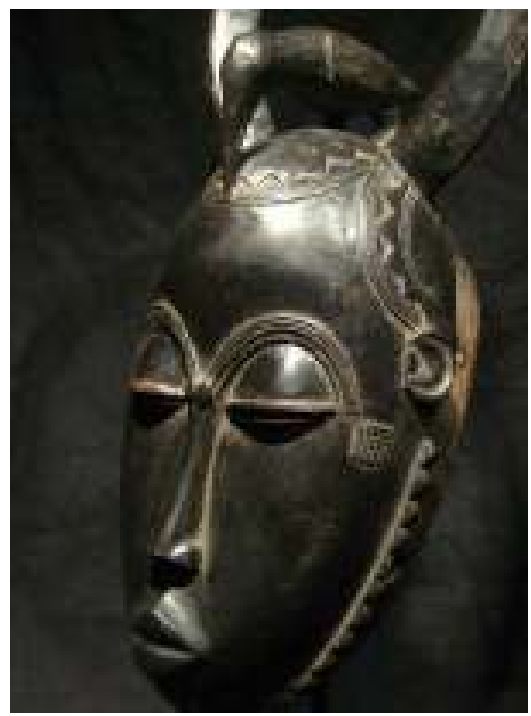

Figure 7\& 8: Wooden African masks

\subsection{Mask}

Masks are usually worn as disguises and used in masquerades. But they are sometimes used for display. Masks are made from a variety of materials. They may be carved of wood and painted with pigments made from plants or minerals. These are decorated with animal skins, feathers, or beads. Artists making masks out of 
paint fibers, tree bark, metal, or other materials are also common. Face masks are only one type of mask. The helmet or "bucket" mask covers all or half of the head. Crest masks are worn on the top of the head. Africans believe that Masks are supports for the spirits. According to traditional beliefs, spirits are found in nature and in humans and animals. Some spirits are considered gods. Masks may represent male or female s pirits. But they are almost always worn by men. During the performance, a masked dancer is no longer himself. $\mathrm{He}$ is the spirit that the mask represents. Masks perform a variety of functions. They may be used in rites marking the transition from childhood to adulthood, in the marriage ceremonies or to enforce the laws of society. Or they may be used to cause rain to fall during periods of drought or to celebrate gods and ancestors. Masks are possessions of central Africa; especially they inherited the carving practice of Angola. Ceramics masks of Transvaal of $800 \mathrm{AD}$ in southern Africa perhaps have some link with gold-covered objects excavated at Mpungubwe. These are certainly precursors of stone sculptures of Zimbabwe. (Ivan, 1992)

\subsection{Sculpture}

In the African art, carved figures are used to guard containers filled with sacred relics of ancestors and the heads of the figures are several times larger than the heads of real human beings, which is also common for the masks. This is a stylistic convention that, with slight variations, can be observed in the art of most African peoples. We do not know why this convention was used through all the parts of this vast continent from the very beginning of art history. In most cases for African sculptures, the head is emphasized because it is the most vital part of the body. Some stylistic characteristics, however, are common to the entire continent. These characteristics are - simplified forms, balanced and symmetrical designs, and unemotional facial expressions. Although the form of a face or figure may be minimal, the details are both precise and abundant. Except, Ifé (being seen as the consequence of Nok) and Benin sculpture represents a very different tradition from its naturalism, it is closer than any other type of art in Africa. For exemplification, in the Nok culture; archaeology revealed such evidences which are the earliest evidence of African art, a plastic art form yet to be found, flourished in northern Nigeria from about 500 B.C. to A.D. 200. Nok was not a closed entity and found from Tegdaoust to Jenne-Jenno in Niger, south of Lake Chad and no doubt; elsewhere, notably at Igbo-Ukwu as well. This tradition was not only expressed in ceramics but also in metals and wood in 1100AD. West Africa practiced figurative art of baked clay. A rich Stone culture of sculptures developed at Gokomere in Zimbabwe, which died out in $11^{\text {th }}$ century, while a less complex rock art styles continued in South Africa and Namibia, like works of San. The Spread of stylistic provinces is not decent, but only vague ideas about the role played by these arts and their purposes.We can hope that some gaps will be filled and then able to reconstruct an art history of regional traditions in Africa. (Ivan, 1992)
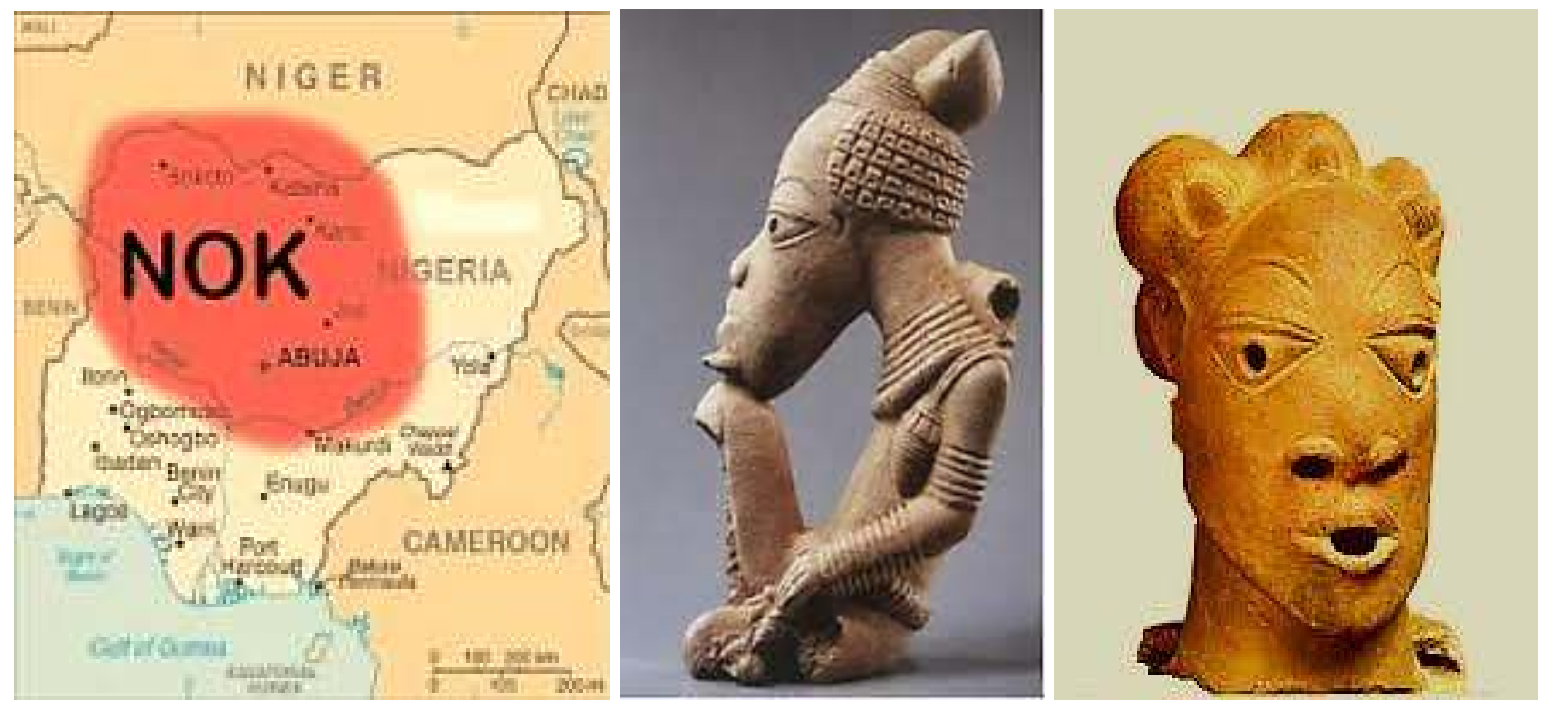

Figure 9, 10 \& 11: Location of ancient Nok culture, Nigeria. Sculpture found in excavation and Bust of woman 


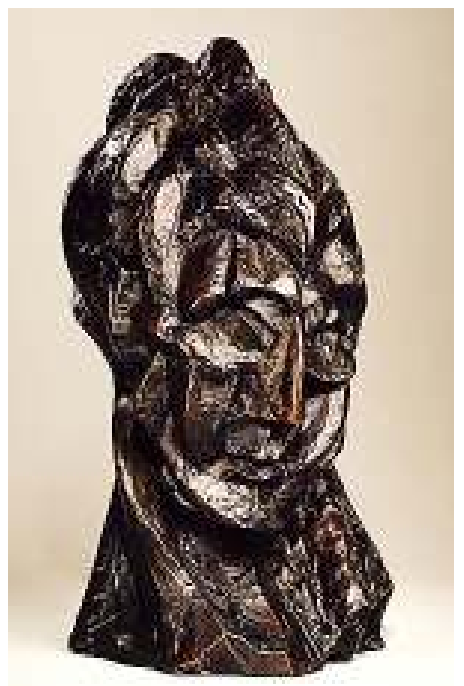

Figure 12: Head of a Woman, 1909by Picasso (Spanish, 1881-1973), a cubist sculpture. Bronze; 16 × $10 \quad 1 / 4 \times 10$

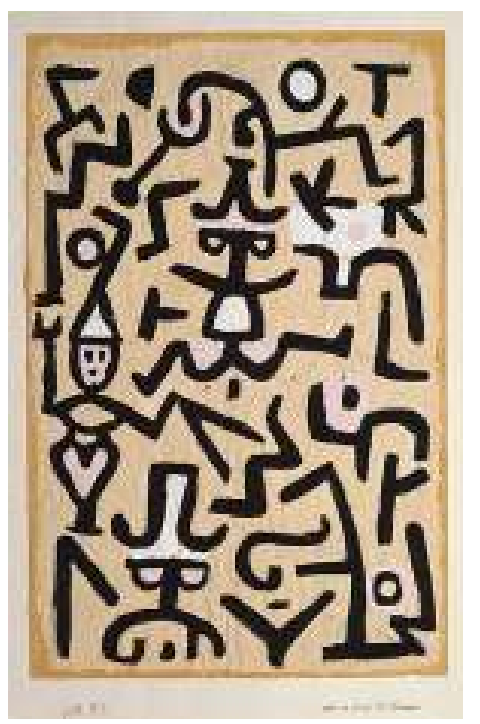

Figure 13: Comedians' Handbill, 1938 by Paul Klee (German, 1879-1940) Gouache on newsprint; $19 \quad 1 / 8 \quad$ x $12 \quad 5 / 8$

\subsubsection{The Stylistic Influences of African Sculpture}

The plastic concepts of the blacks of Africa and their influence were purely stylistic, in Europe and this was not derived from a profound reflection on the true means of representation and of construction as those of the African sculptors. But they managed, at least; the liberating effect of these cultures offered as alternatives to the stifling social mores and expectations of European society. Reacting in a romantic way they were, above all; emotionally moved. Stylistically, they borrowed bold volumetric shapes, geometric ornamentation, decorative patterning and flattened planes from African art and objects, encountered in ethnography.

Modernist artists were drawn to African sculpture because of its sophisticated approach to the abstraction of the human figure. In fact, the clear understanding of the proportion of African sculptures, their own sense of design, and their acute sense of reality has affected the European perceptions, even opening up new paths for them to dare to explore as the representational style is therefore abstract rather than naturalistic. The abstract form of the African sculptures, masks and artifacts go even further to serve its function and are also collective. To support this view, Ceramic vase of Sintiu-Bara of Senegal is considered as a cultural indicator over a much wider geographical area of Africa. The exaggerated flatness of these sculptures, reliquaries to be exact and lack of affects, typifies the basic elements of African aesthetics that were frequently evoked in modernist painting and sculpture.(Murrell, 2008)In the postcolonial and contemporary era, the influence of traditional African aesthetics and processes is so profoundly embedded in artistic practice that it is only rarely evoked

as such. 


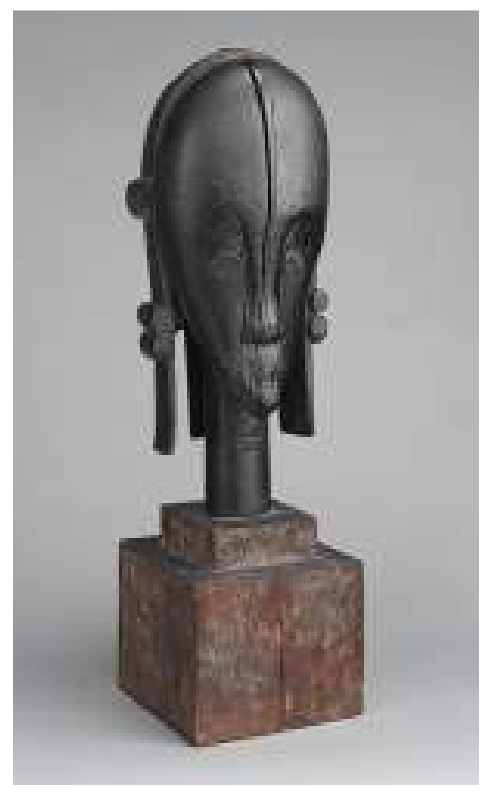

Figure 14: Reliquary Head (NloBieri), 19th-20th century Fang, Betsy group; Gabon. Wood, metal, palm oil; $46.5 \mathrm{x}$ $24.8 \times 16.8 \mathrm{~cm}$

\subsubsection{An example: Reliquary Head}

The Fang sculpture exemplifies the integration of form with function that had created a centuriesold tradition of abstraction in African art before the European colonial period. Affixed at the top of a bark vessel where remains of the most important individuals of an extended family were preserved by a sculpted head by the Ambete artists of Gabon. The sculptural element can be considered as the embodiment of the ancestor's spirit. These are symbolized as the actual receptacle of the ancestral relics. For information, such Ambete reliquary was once owned by the pioneering Paris dealer Charles Ratton and then by Pierre Matisse, son of the famous artist.

\subsection{Organic Architecture}

A wide range of architectural forms can be found in Africa. The most noteworthy stone architecture by indigenous Bantu people is the complex of buildings at the ancient city of Great Zimbabwe in southern Africa. It was constructed during the 1100 's to the 1400 's. It is remarkable because of its great size and the stone walls were assembled without mortar. The ruins cover nearly 1,800 acres and divided into three distinct architectural groupings- Hill Complex, the Valley Complex, and the Great Enclosure. At its apogee in the late fourteenth century, Great Zimbabwe may have had as many as 18,000 inhabitants. A series of residential and ceremonial enclosures, the interiors, and its outer wall were built in deferent stages and the Hill Complex erected in 1250 A.D, sits atop a granite dome that overlooks the rest of the site. The smaller Valley Complex, dated to the early fifteenth century, was the last of the architectural undertakings. (McIntosh, 1998) 


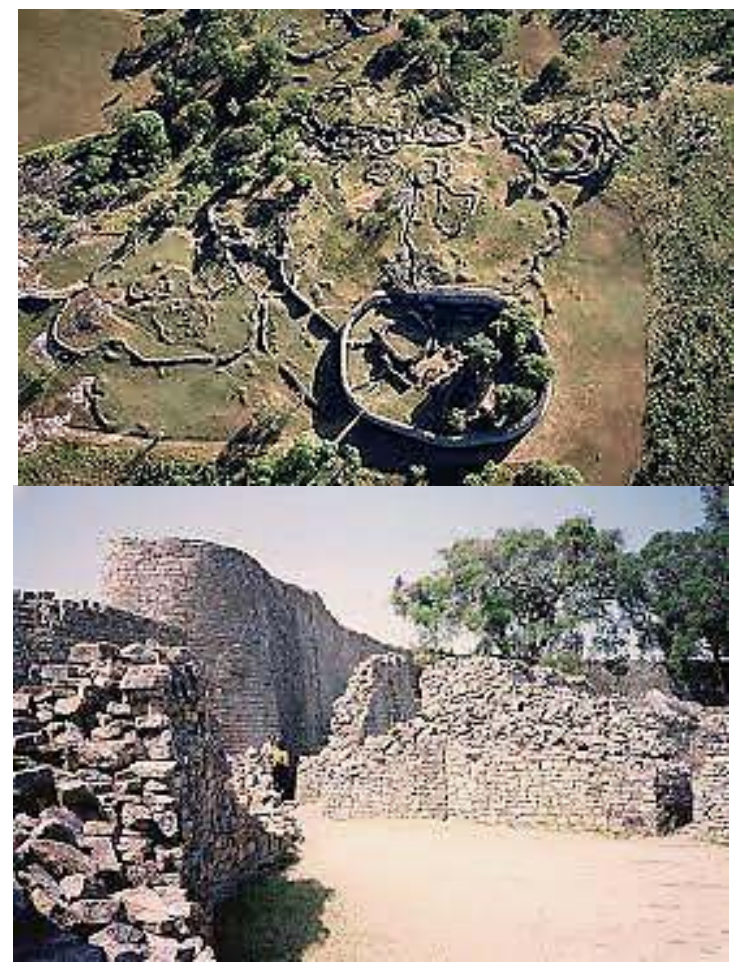

Figure 15 \& 16: The ruins of Great Zimbabwe, organic development of Africa's own

\subsubsection{Vernacular pattern}

The simplest houses are the beehive-shaped houses of the Pygmies of central Africa. The frames of such houses are constructed with flexible branches that are covered with large, fresh leaves. This type of temporary housing suits the Pygmies' nomadic way of life. Agricultural people, in contrast, require sturdy and permanent houses. Houses may be built with thick mud walls or with sturdy bamboo frames. Roofs may be thatched or covered with corrugated metal. The royal palaces of the Cameroon in grass fields are outstanding examples of bamboo-frame structures. Some reach heights of more than 25 feet (7.6 meters). Important buildings are ornamented with carved and painted doors, door frames, and posts to support the veranda roofs. (Walker, 2014)For example, let us consider the palace of the chiefin Logone-Birni, Cameroon. At left on this page is an aerial photo of the place of the chief. "Load Demo" provides a simulation which better reflects the density of rooms and this simulation is obviously a golden rectangle, which can be recursively subdivided. But the first opinion may be more conceptually accurate: notably, the map of the path to the throne room (in middle image) approximates a golden spiral. The royal insignia (right) includes three iterations of scaling rectangles; they are well aware of the scaling properties of their architecture. The mystery lies in a mathematical order, fractals; discussed in the next paragraph. In addition, with some exceptions; African village is not a concentrated cluster of houses geometrically located along a path. Africa has been and still is characterized by a settlement pattern to which the term 'village' has been applied. This seemingly haphazard forms of residence but doesn't seem isolated to the African. (Burke, 1964) 


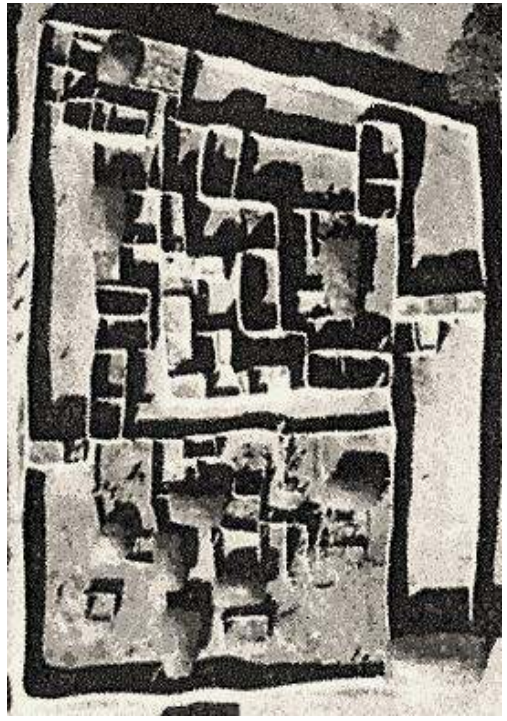

Figure 19: Royal insignia

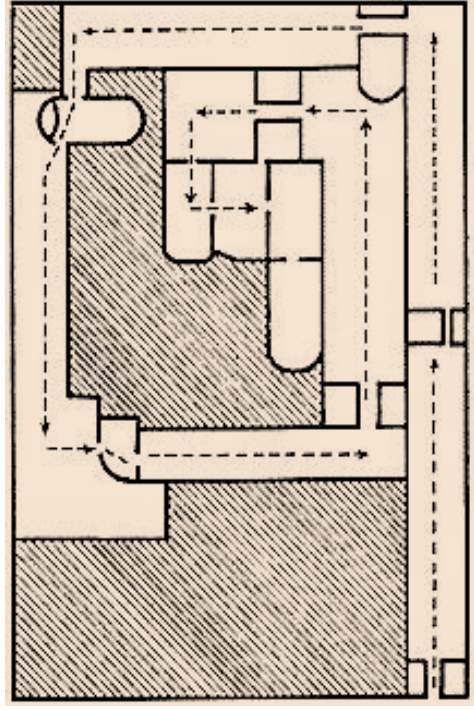

Figure 18: Circulation pattern

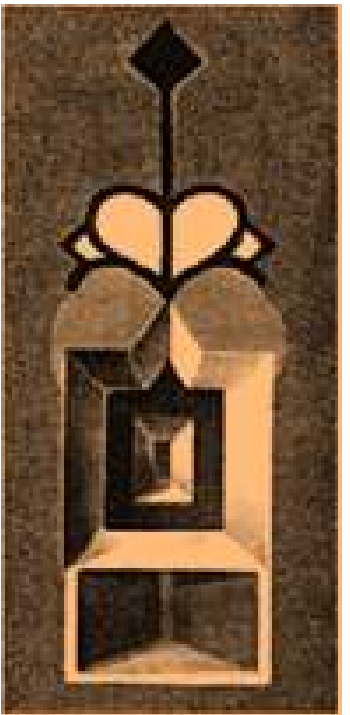

Figure 17: Chamber of chief, Cameroon

\subsubsection{Fractal art in architecture}

The concept of fractal extends beyond selfsimilarity and includes the idea of a detailed pattern repeating itself. The newfangled conception of fractal patterns that means mathematical, recursive patterns that explain the geometry of nature, with smaller parts mirroring larger parts which examine the underpinning architecture, art and design in many parts of Africa. (Albers, 2008)Fractal geometry and mathematics are prevalent in African art, games, divination, trade, and architecture. Simply, circular houses appear in circles of circles, rectangular houses in rectangles of rectangles and so on.

Observing the aerial-views and then following up with detailed research on the ground floor plans, one can discover that many African villages are purposely laid out to form perfect fractals, with self-similar shapes repeated in the rooms of the house, and the house itself, and the clusters of houses in the village, in a mathematically predictable patterns. Fractals also form the basis for the layout of African villages and the patterns that appear in African art. The fractals are at the heart of African design. It's more than just aesthetics: the scaling structure provides a practical means of providing airflow and improving building's ecological fit. (Eglash, 2007) In addition, when Europeans first came to Africa, they considered the African architecture as much disorganized and thus primitive. It never occurred to them that the Africans might have been using a form of mathematics that the Europeans hadn't even discovered yet. (Eglash, 1999) 


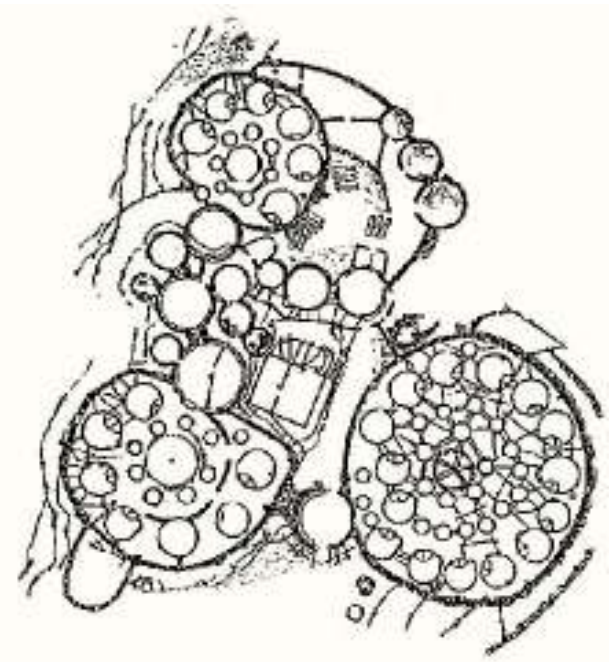

Figure 20: Bird's eye view of plan of Ethiopian village fractals
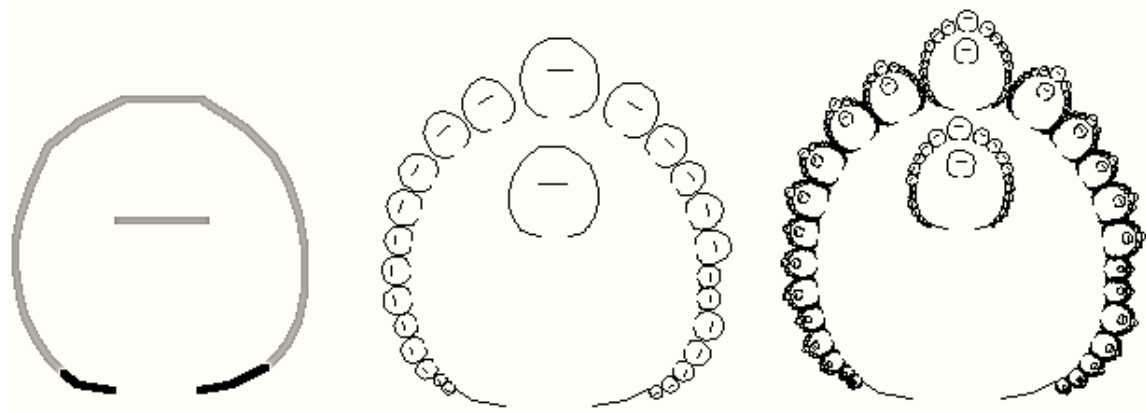

Figure 21: First three in iterations of fractal model in dwellings of African village 


\section{Case studies}

\subsection{Bauhaus Evidence: the African Chair}

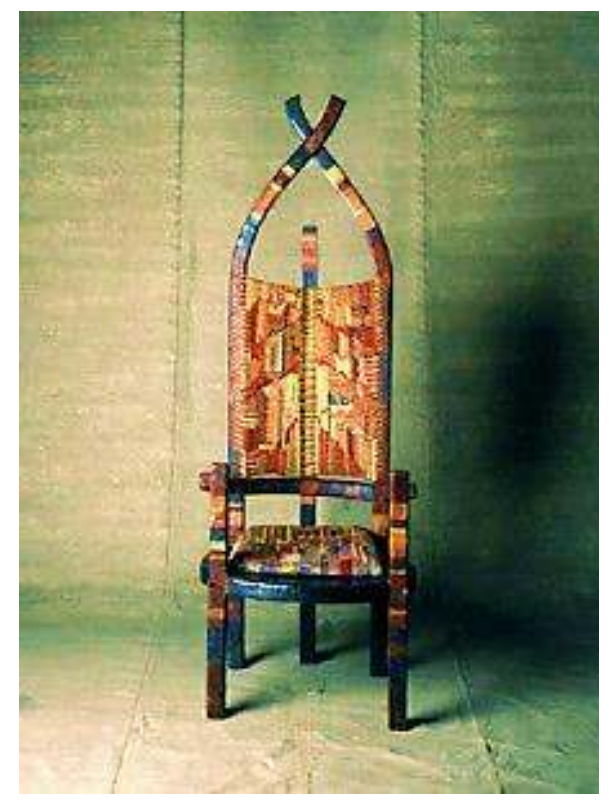

Figure 22: African chair of Bauhaus by Marcel Breuer and GuntaStölzl

A work from the early years of the Bauhaus, presumed lost for the past 80 years, has been recovered; with the support of the Ernst von Siemens Art Foundation, it was possible to secure this legendary and unique work for the collection of the Bauhaus Archive in Berlin. It is the African Chair, a throne-like piece of furniture created by Marcel Breuer in collaboration with the weaver GuntaStölzl. Even today, the colorfully painted and upholstered oak chair evokes visual associations that are linked to its title. Made of painted wood with a colorful textile weave, this chair embodies the spirit of the early Bauhaus like no other object. It is the first work by Marcel Breuer, who later went on to write design history with his tubular steel furniture.

However, what was the original purpose of the chair? A wide range of hypothetical uses at the time of its inception are possible:
1. The chair could have served as a 'throne' for the Bauhaus director, who defined his role as master of a building lodge in accordance with the self-image of the early Bauhaus.

2. The throne-like construction could also refer to the understanding of architecture as the mother of all arts in classical architectural theory, with the architect as leader and organizer - a role with which Walter Gropius identified all of his life.

3. Equally conceivable is the interpretation of this piece of furniture as a symbolic wedding chair, giving expression to the close relationship between Marcel Breuer and GuntaStölzl at the time. 


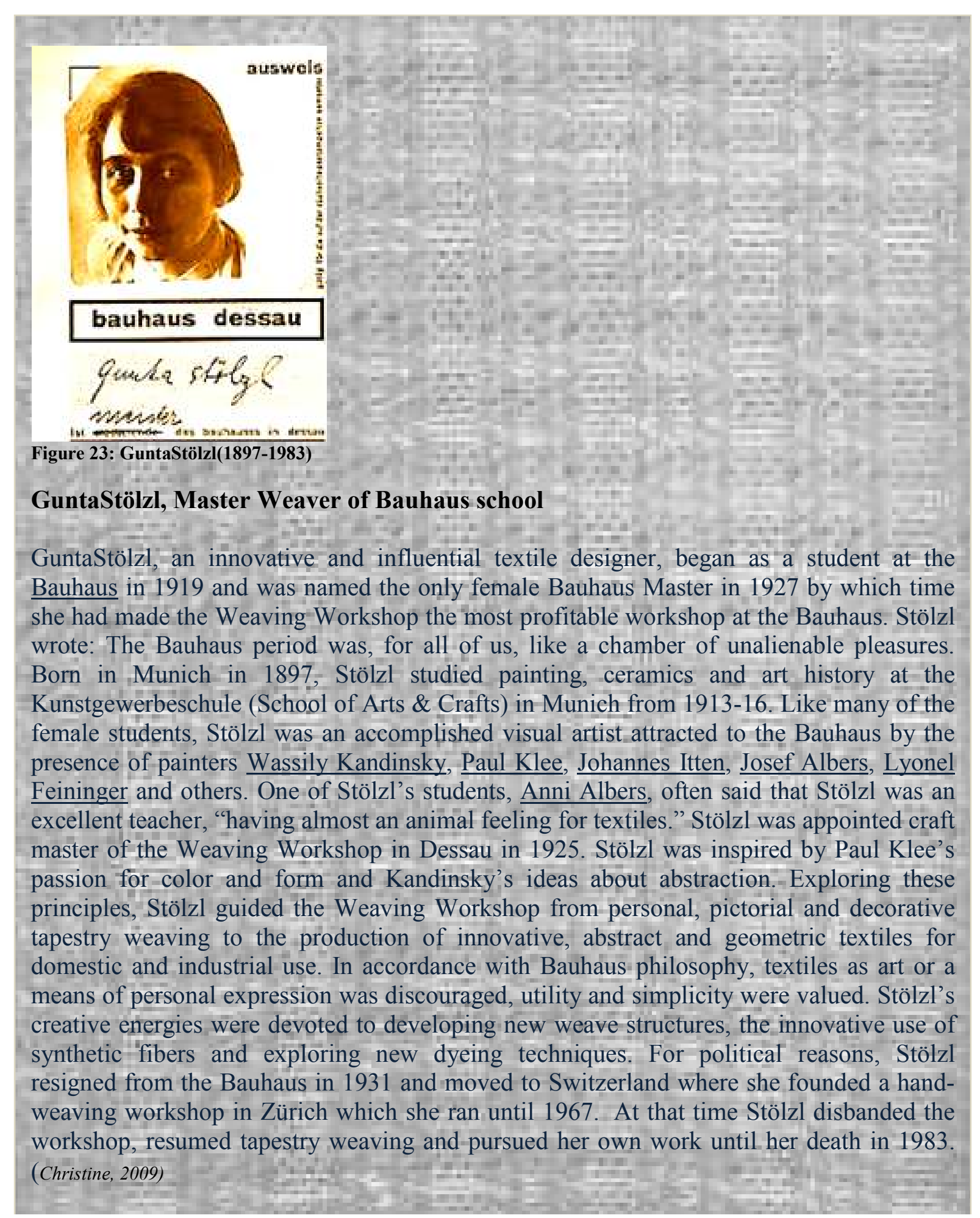


All of these attempted explanations are filtered from the many ideas and theories that were circulating simultaneously in the early years of the Bauhaus; with the emergence of the Bauhaus maxim, 'Art and Technology - A new unity' beginning in 1923, the chair became a symbol for an early era of Bauhaus history. Accordingly, it is a peerless physical manifestation of the complex conceptual universe of the early Bauhaus. Neither on that time nor later was any specific comments made regarding the chair. The Bauhaus Archive presents this chair by emphasizing its unique significance within the context of additional works from the early Bauhaus which also includes a representation of the attempts to demonstrate the development of furniture design at the Bauhaus - from the African Chair to tubular steel furniture. (In-depth Arts News,

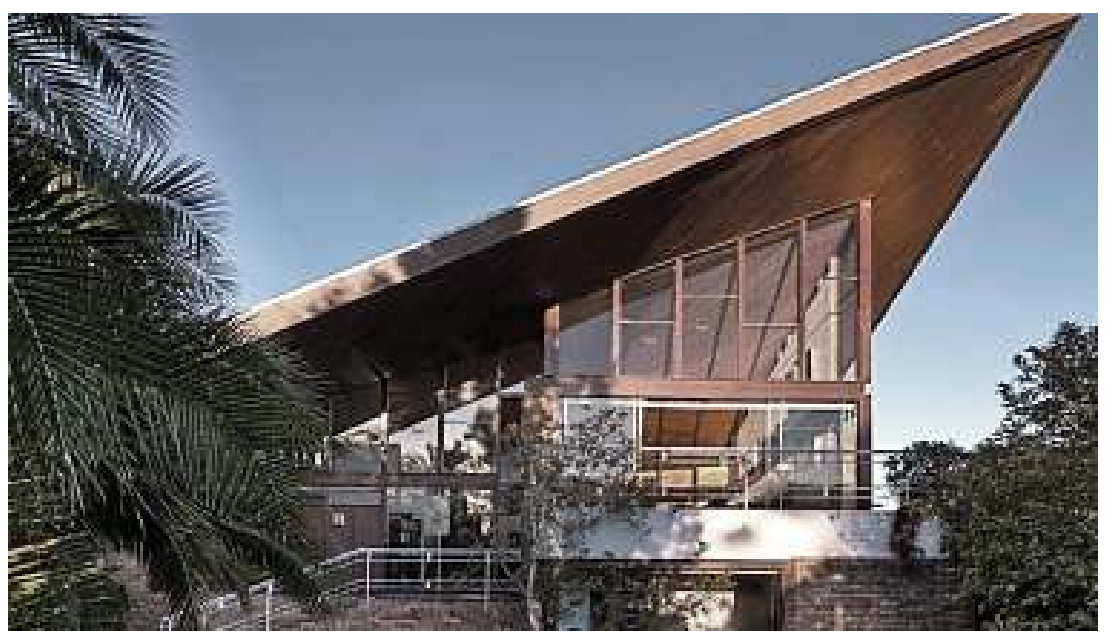

Figure 24: Bruynzeel House, De HogeHoek at Stellenbosch, South Africa, 1962

\author{
'Architect Pius Pahl, a German architect \\ of Bauhaus school; where hewas trained \\ under Mies van der Rohe. Pahlmarried a \\ South African woman and moved to \\ Stellenbosch after World War II, In \\ 1952. He opened up a practice in \\ Stellenbosch and designed what is now \\ the biggest collection of private homes of \\ Bauhaus tradition in South Africa that \\ formed a new socialist order. He is \\ considered as the first introducer of \\ Modernist architecture in Africa and \\ Taught at Cape Town School of \\ Architecture.Received the Gold Medal \\ Award of South African Institute of \\ Architects in 2001'
}




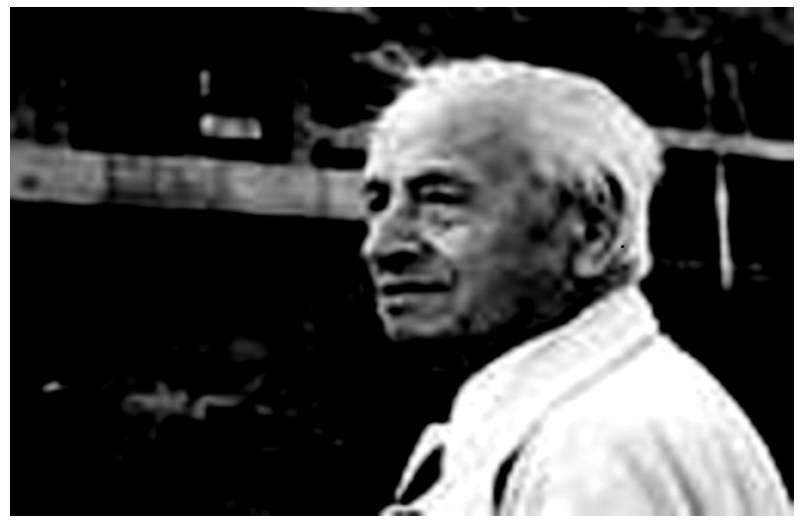

Figure 25: Architect Pius Pahl (1909-2003)

\subsection{Bruynzeel house: the legacy}

The Bruynzeel house, De HogeHoek, in Stellenbosch was built quite some time after the end of the Bauhaus movement, in 1962. It was designed by architect AartBijl, who was a student of the well-known Bauhaus architect Pius Pahl, introduced modernism in the continent.

His famous work 'HuisStruwig' is a representation of his own craftsmanship as well as the Bauhaus ideology, but for this study; work of his student is chosen to evaluate his far reaching sway. Bruynzeelis an example of late modernist practice of Bauhaus architectural influence in South Africa. Here, it can be seen as the obvious influence of the owner, KeesBruynzeel; a wood merchant and yachtsman in the fine use of wood, and dramatic hyperbolic slanted roof with almost a sail-like, nautical feel to it. This is combined into a very artistically and aesthetically pleasing architectural building by the architect's influence. Despite the fact that most Bauhaus style roofs were typically flat, this modern building takes on the style that has a roof the shape of a hyperbolic paraboloid, but still allows for the straight clean lines which are characteristic of Bauhaus.
Another modern day departure of Bruynzeel house from the normal Bauhaus style is in the use of color. Whereas Bauhaus used colors of white, gray, beige or black; here the raw materials of wood and brick are on display, but they are still featured in such a way that they create a neutral palette and certainly, not in bright colors. We know that one of the key elements of the International Style in Europe was a large window. Here, the use of windows dominates the façade of this building, creating clean dominantly cubist shapes of typical Bauhaus. The windows at the top and bottom are of different proportions; in line with the favoring of asymmetrical over symmetrical.

Windows create a geometric aesthetic, without ornamentation of any kind. The abundant use of windows also leans to the Bauhaus characteristic of space over mass. The use of these high windows, fitted into the amazing roof; are certainly functional and yet beautiful. In fact, the Bauhaus Institution called for housing for the working classes and as such, used the principles of Classical architecture in their most pure form. In other words, they shunned ornamentation and favored functionality. 


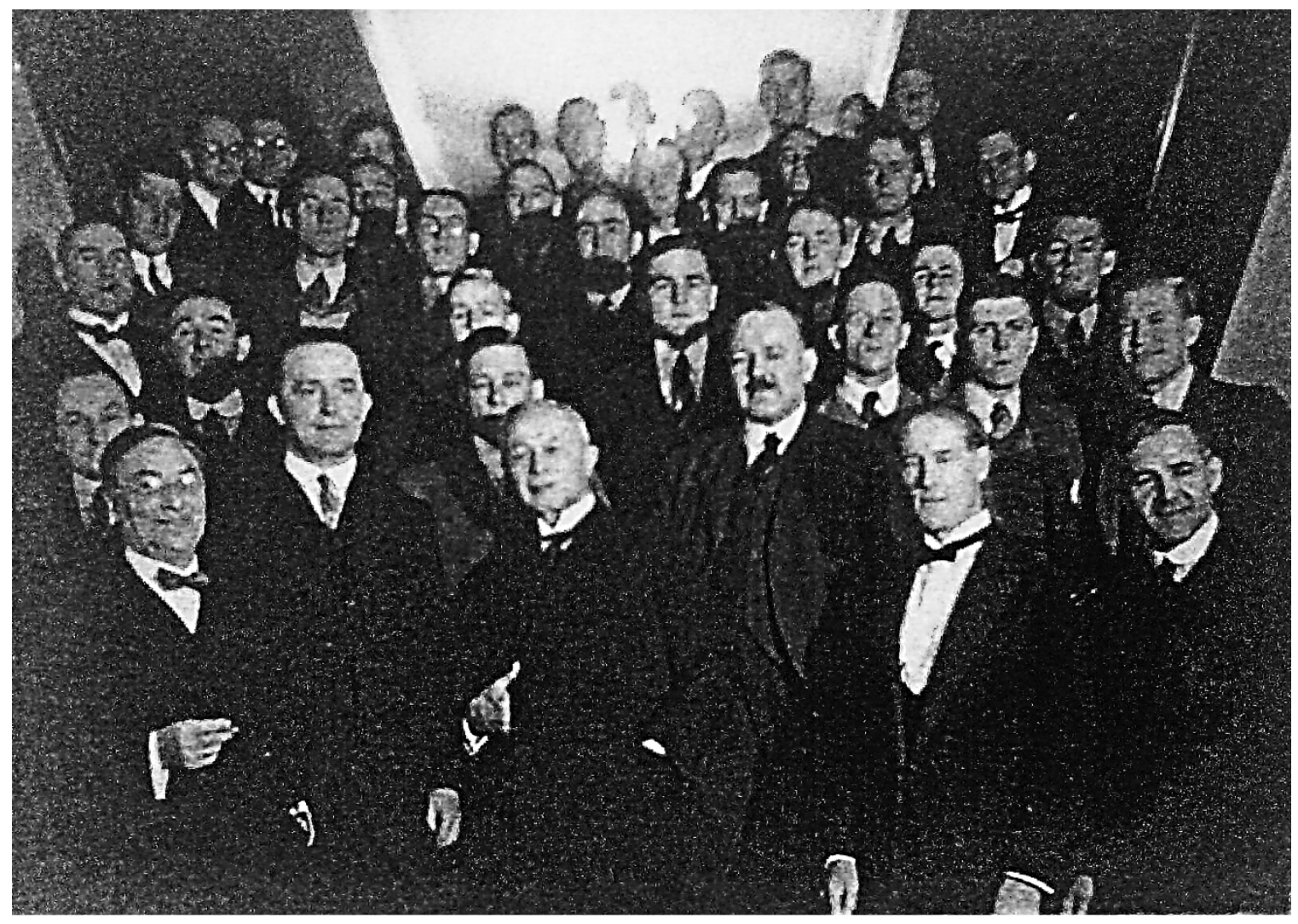

Figure 26: Bauhaus visit by South African students in 1929 at Dessau, front row from left: Wassily Kandinsky, Fritz Hesse, Hugo Junkers, unknown, prof. Bohle (South African professor) and Hannes Meyer in right.

\section{Outcome of the study}

For Bauhaus, it produced an alternative emancipation from the classical meanings, wanted to deny the conventionality and designed for the universal, but the abnormality of its birth 'fit for everywhere' couldn't prevent it from the 'adaptation' which eventually let the regional modernism to rise, that pivoted from the African thought- Craft quality in material use. Again, fenestration and climatic solutions got priority instead of 'foolish' ornamentation. Thanks to Bauhaus, that it's bold opposite mind helped masters like Frank Lloyd Wright and Alvar Aalto to create 'intimate' architecture, although; both have some indebt belong to Bauhaus. Considering all the pros and cons, this study wants to recommend some acuity that would be collective for architectural practice of a climatically challenged and fatigued world. The propositions are illustrated next:

\subsection{Architecture as artifacts: dexterity}

Despite triumph of technological advancement, the practice of architecture may still be regarded as a craft; that is, dedicated to the significant formulation and reflection of human environment. We have to remember that architecture, like the catalyst, compels us to accept some skills that are required to produce such artifacts, based on tradition and ideology. The ambivalent nature of history wedged between the technological triumph and crafts is continuously seeking to accommodate between continuity and change. Architectural criticism occupies the no-man's land between poetic sympathy and rational analysis. Still, Architects, like an artist have to; visualize the image of the object in his mind's eye. Architecture is a cultural phenomenon and a system of culture, based on aesthetic representation, while craft could be spurring. 
Looking at architecture, as an art form like sculpture, one finds a great deal of architecture presents itself as exuberantly plastic. Needless to say one cannot exclude the sculptural identity from the full expressive range of architecture. However, the sculptural need not be divorced from either the structural or the spatial and has to be borne out of tectonic assemblies. The design solution should maintain that, it is the designer's working details and materials which remain the option for architectural imagery that can leave some scopes for dexterities.

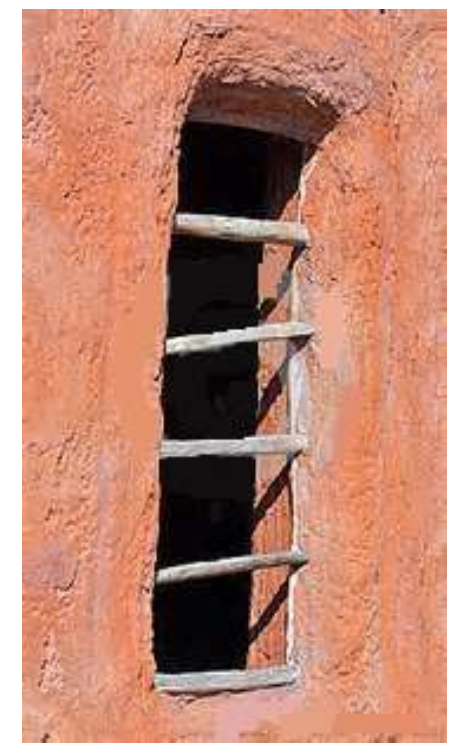

Figure 27: Window in a mud hut, West Africa

\subsection{Nature and architecture: window}

Architecture is the symbolic language, where origin lies in nature and our response to it. Architecture is an outcome of reasoning, setting itself against the nature, as a metaphor which again is collected from natural forces. Articulation of sun and light and protective details for rain combined with sensitive integration of vegetation and tectonic form creates the fabric of architecture, within a natural surroundings. (Anker, 2010)While designing, we have to keep in mind the whole range of sensory perceptions, which is enumerated by the body such as intensity of light, darkness, humidity, heat, cold and breeze; choice of building materials should be on the basis of a better understanding of these sensory perceptions. Window is the point at which the natural forces like light, breeze and climate impinge upon the outer membrane of the building. As such, architectural presentation has an innate capacity to inscribe architecture with the character of the region and hence, to express the place in which the work is situated. This generates the appearance of a place, conscious poetic created by an interaction between culture and nature. Again, an unceasing regional inflection of form arises directly from the fact that in certain climate, for instance, the glazed aperture is advanced while in others it is recessed behind the masonry facades. Nature wants to speak with the man, man wants to speak with the nature, and window is the summit place for this discourse, while the crafts are the written forms of their dialogue.

\subsection{Theorizing of architectural fabrication: obedience}

Architecture transcends the mere pragmatism of building by the virtue of assuming symbolic significance. The 'Inorganic' has no symbolic meaning. Structural form can only acquire symbolic value by virtue of its capacity to engender analogies between tectonic and organic form. (Andrew, 2002) Architecture, 
simultaneously; serves both as a metaphor of and as a foil to the naturally organic. The architectural project should develop from the materiality of environment. The architect must recognize the site in the midst of an unknown universe in order to take account of it and modify it. What can an architect do? Simply, return to his or her roots.

1. Architect should attempt to derive the entire syntax of a building from structure and construction and necessities of construction, supplemented by economic and social considerations; where tradition may assist him.

2. Architect should recognize that, the universal aesthetic can be predicated only on the conditions of symmetry richness of materials and precision of execution. Architectural examples of significance indicate a striving for structural perfection, which contributed in a great part to their impressiveness, clarity of form and a logical scale which mankind have been obtained and developed from the skills of craftsmanship, that they inherited by instinct.

3. Architects should develop an ability to aspire an 'order' in design which would rise above the decorative and eclectic historicism, instead of developing a capacity to combine and recombine ruined fragments of a lost civilization. Civilization can be destroyed but the idea is immortal.

4. Architect should be free to combine primitive and sophisticated techniques, according to their needs and resources. He or she may use intermediate technology and indigenous materials, for which we are indebted to ours ascenders.

In architecture, the creative capacity of the culture, as a whole; is of more consequence than the contribution of any particular architect. Priority is to the social culture of the art, rather than emphasizing on the presence of any singular talent.

\section{CONCLUSION}

Traditionally, African art piece contains the areas of compositions that encompass passages of color in pure geometric patterns in any surface to relate certain forms of lyrical abstraction. Despite the simplicity of its pattern, the composition imparts an almost architectonic sense of scale and structure, which might have favored the base for Bauhaus trend. On the other hand, Bauhaus represented a belief in the unifying power of geometry, something we no longer can share but is still relevant. The Bauhaus was more than just an idea, of course; it was an actual institution. While these artist-engineers knew a little of the original meaning and function of the African art that they encountered, they instantly recognized the spiritual aspect of the composition and adapted these qualities to their own efforts to move beyond the naturalism, which had defined Western art since the Renaissance. But against those who idealize avant-garde utopias, it is also important to see that this was 'Displaced' energy, responding to the right questions but unable to provide the answers to them on its own. In this sense, the ultimate lesson of the Bauhaus, for today, is that art cannot afford to turn away from history. This study is eager to proclaimthat,Africa ignited the fuel of European thought earlier and Bauhaus, as a global diaspora; bore the legacy to mark an epoch later.Sharinga drastic origin; both are the indispensable part of human achievement in history.

\section{REFERENCES}

Andrew Ballantyne., 2002. Ed. 'What is architecture?' chapter 8: Botticher, Semper and the tectonic: core form and art form by Kenneth Frampton, page 139, Rout ledge, 2 park square, Milton park, Abingdon, Oxon,

Albers, Donald J., Alexanderson, L. Gerald., 2008. "Benoît Mandelbrot: In his own words". Mathematical people: profiles and interviews. Wellesley, MA: AK Peters. Page 214,

Ben Davis., 2014. 'The Bauhaus in history', associate editor art net magazine, NY, USA

Christine Cariati, Venetian Red Art Blog, October 31, 2009

Dr. Jeanne S. M. Wilmette., 2011. Art History Unstuffed, part 2, Oct 28,

Fred G. Burke., 1964. 'Africa's quest for order', chapter 3: tribes and tribalism, page 24, Prentice Hall, Inc. Englewood cliffs, New Jersey, USA,

Griffith Winton, Alexandra., 2000. "The Bauhaus, 1919-1933" thematic essay, Heilbrunn 
Timeline of Art History. New York: The Metropolitan Museum of Art,

Herbert Read., 1968. 'The meaning of art', page 89, June, penguin study edition, London,

Ivan Hrbek., 1992. edited 'UNESCO general history of Africa III: Africa from the seventh to eleventh century: five formative centuries', abridged edition. Chapter 28: collective representations: religions, ideologies, arts by J.Devisse and J.Vansina, page 377, 7 Palace de Fontenoy, 75700, Paris,

Ivan Hrbek., 1992. edited 'UNESCO general history of Africa III: Africa from the seventh to eleventh century: five formative centuries', abridged edition. Chapter 28: collective representations: religions, ideologies, arts by J. Devisse and J.Vansina, page 376, 7 palace Fontenoy, 75700, Paris,

In-depth Arts News:"The African Chair: Marcel Breuer and GuntaStölzl with Works by Bauhaus Artists", Bauhaus Archive, Museum fürGestaltung Berlin, Germany, June, 2004

Michel Leiris e Jacqueline Delange, 1967. 'Africa Nera', chapter: African Art and European Artists, Feltrinelli,

Murrell, Denise. "African Influences in Modern Art", Heilbrunn Timeline of Art History. New York: The Metropolitan Museum of Art, 2000. http://www.metmuseum.org/toah/hd/aima/hd aima.htm (April 2008)

Peder Anker, Baton Rouge, 2010. 'From Bauhaus to Eco house: A History of Ecological Design', Louisiana State University Press, p. 216,
Ray Faulkner, Edwin Ziegfeld, 'Art Today', sixth edition, chap. 16, page 397, Holt, Rinehart and Winston, Inc. New York, November, 1986

Roderick J. Mclntosh, 1998. 'Archaeology', the Archaeological Institute of America publication, Volume 51 Number 4, July/August

Ron Eglash, 1999. African Fractals: Modern Computing and Indigenous Design. New Brunswick: Rutgers University Press,

Ron Eglash, 2007. African Fractals Culture 2: Logone-Birni: Ethno-mathematics, November 29 ,

Roslyn Walker, 2014. Curator, National Museum of African Art, 'African Art and Architecture, The New Book of Knowledge', Scholastic Inc. May,

William Harbutt Dawson, 1919. 'The German empire (1867-1914) and the unity movement', volume II, chapter 17: the colonial era; page 210; George Allen and Unwin Itd, London, 